\title{
Investigation of bacterial microbiota and risk factors in dogs with external ocular diseases from Bandeirantes, Paraná State, Brazil
}

\section{Investigação da microbiota bacteriana e associações de risco em cães com afecções oculares externas atendidos em Bandeirantes, Paraná, Brasil}

\author{
Ademir Zacarias Junior ${ }^{1 *}$; Julio Cesar de Freitas ${ }^{2}$; \\ Francielle Gibson da Silva Zacarias³; Rogério Salvador' João Luis Garcia ${ }^{5}$
}

\begin{abstract}
For the determination of the bacterial etiology of the external ocular diseases and sensitivity to antimicrobials, $38 \mathrm{dogs}$ with external ocular diseases, unilateral or bilateral, and $120 \mathrm{dogs}$ without ocular diseases (control group), were studied between 08/2008 and 07/2009 in the Veterinary Hospital of North Paraná State University, Brazil. The collected samples of the inferior conjunctival sac were incubated at $37^{\circ} \mathrm{C}$ in an aerobic environment, in blood agar and MacConkey agar, for 120 hours. After the presumptive identification, the bacterial species were identified by the systems APISTAPH (bioMerieux, Incorporation), API 20 STREP (bio-Merieux, Incorporation) and BACTRAY (Laborclin, Ltd.) and incubated in Mueller-Hinton agar with antimicrobials disks, for sensitivity determination. For the risk factors, the owners answered a questionnaire with epidemiological variables. There was microorganism growth in $46(73.02 \%)$ samples, with isolation of one microorganism in 42 samples and two microorganisms in four. Gram-positive bacteria corresponded to $76 \%$ of the isolated, Gramnegative $20 \%$ and yeasts fungi $4 \%$. Staphylococcus spp totalized $66 \%$ of isolated, with S. aureus $(24 \%)$ and $S$. intermedius (24\%) the most prevalent. With the exception of $S$. intermedius $(91.67 \%)$ and $S$. epidermidis (66.67\%), the isolated bacterial species presented $100 \%$ resistance to the sulfonamide. The $S$. aureus isolated presented $91,67 \%$ sensitivity to chloranphenicol, tobramycin and amoxicillin/ clavulanic acid, and the same percentile of resistance to tetracycline. The $S$. intermedius presented $100 \%$ sensitivity to amoxicillin/ clavulanic acid and $91,67 \%$ to gentamicin and $75 \%$ resistance to tetracycline and ceftriaxone. The associations of risk for external ocular diseases were clinical returns $(\mathrm{OR}=59,50,7,29<\mathrm{OR}<1305,07, \mathrm{p}=0,00000)$, use of topical antibiotics $(\mathrm{OR}=19,67,3,59<\mathrm{OR}<142,50$, $\mathrm{p}=0,00003)$, use of topical corticoids $(\mathrm{OR}=19,83,2,08<\mathrm{OR}<474,07, \mathrm{p}=0,00232)$ and ocular cleansing $(\mathrm{OR}=23,00,6,80<\mathrm{OR}<82,90, \mathrm{p}=0,00000)$. The realization of microbiological examinations is essential for the adequate treatment of ocular diseases.
\end{abstract}

Key words: Staphylococcus spp, diagnostic, antimicrobial, antibiotic, conjunctival

${ }^{1}$ Médico Veterinário, MSc., Prof. Assistente, Universidade Estadual do Norte do Paraná, UENP, Campus Luiz Meneghel, Setor de Veterinária e Produção Animal. E-mail: zacarias@uenp.edu.br

${ }^{2}$ Médico Veterinário, Dr., Prof. Titular, Dept ${ }^{\circ}$ de Medicina Veterinária Preventiva, Universidade Estadual de Londrina, UEL, Londrina, PR. E-mail: freitasj@uel.br

${ }^{3}$ Médica Veterinária, Prof ${ }^{\mathrm{a}} \operatorname{Dr}^{\mathrm{a}}$ Adjunta, UENP, Campus Luiz Meneghel, Setor de Veterinária e Produção Animal. E-mail: franciellegs@yahoo.com.br

${ }^{4}$ Médico Veterinário, Prof. Dr., Adjunto, UENP, Campus Luiz Meneghel, Setor de Veterinária e Produção Animal. E-mail: salvador@uenp.edu.br

${ }^{5}$ Médico Veterinário, Prof. Dr., Associado, Dept ${ }^{0}$ de Medicina Veterinária Preventiva, UEL, Londrina, PR. E-mail: jlgarcia@uel.br

* Author for correspondence 


\section{Resumo}

Para a determinação da etiologia bacteriana das afecções oculares externas e perfil de sensibilidade a antimicrobianos, 38 cães com doenças oculares externas, unilaterais ou bilaterais, e 120 cães sem doenças oculares (grupo controle), foram atendidos entre 08/2008 a 07/2009 no Hospital Veterinário da Universidade Estadual do Norte do Paraná. As amostras coletadas do saco conjuntival inferior foram semeadas em ágar sangue e MacConkey e incubadas em aerobiose a $37^{\circ} \mathrm{C}$ por até 120 horas. Após a identificação presuntiva, as espécies bacterianas foram identificadas pelos sistemas APISTAPH (bioMerieux, Inc.), API 20 STREP (bio-Merieux, Inc.) e BACTRAY (Laborclin, ltda.) e semeadas em agar Mueller-Hinton, para determinação da sensibilidade por meio da técnica de difusão de discos. Para as associações de risco, os proprietários dos 158 cães responderam um questionário com variáveis epidemiológicas. Das 63 amostras, houve crescimento de microrganismos em 46 (73,02\%), com isolamento de um microrganismo em 42 amostras e de dois microrganismos em quatro. Bactérias Gram positivas corresponderam a $76 \%$ dos isolamentos, Gram negativas a $20 \%$ e fungos leveduriformes a $4 \%$. Staphylococcus spp totalizaram $66 \%$ dos isolamentos, sendo S. aureus $(24 \%)$ e $S$. intermedius $(24 \%)$ as mais prevalentes. Exceto $S$. intermedius $(91,67 \%)$ e $S$. epidermidis $(66,67 \%)$, as espécies bacterianas isoladas apresentaram resistência de $100 \%$ às sulfonamidas. Os S. aureus isolados apresentaram sensibilidade de $91,67 \%$ para cloranfenicol, tobramicina e amoxicilina/clavulanato, e o mesmo percentual de resistência para tetraciclina. Os S. intermedius apresentaram 100\% de sensibilidade para amoxicilina/clavulanato e $91,67 \%$ para gentamicina e resistência de $75 \%$ para tetraciclina e ceftriaxona. As associações de risco para as doenças oculares externas foram recidivas clínicas $(\mathrm{OR}=59,50$, $7,29<\mathrm{OR}<1305,07, \mathrm{p}=0,00000)$, uso de colírios com antibióticos $(\mathrm{OR}=19,67,3,59<\mathrm{OR}<142,50$, $\mathrm{p}=0,00003)$, uso de colírios com corticóides $(\mathrm{OR}=19,83,2,08<\mathrm{OR}<474,07, \mathrm{p}=0,00232)$ e realização de limpeza ocular $(\mathrm{OR}=23,00,6,80<\mathrm{OR}<82,90, \mathrm{p}=0,00000)$. A realização de exames microbiológicos é essencial para o tratamento adequado das doenças oculares.

Palavras-chave: Bactérias, Staphylococcus spp, antimicrobianos, diagnóstico, associações de risco

\section{Introduction}

The eye surface is rich in nutrients and, consequently, several microorganisms are found, which constitute the ocular microbiota (ARMSTRONG, 2000). The infectious keratitis and bacterial conjunctivitis are usually enhanced by disruption of the defense mechanism of the ocular surface, which includes the structural integrity and blinking action of the eye lids, the intact epithelium of the conjunctiva and cornea, and the precorneal tear film (WHITLEY, 2000; OLLIVIER, 2003; WANG et. al., 2008).

External ocular diseases can be very severe and clinical signs progress rapidly demanding immediate and intense treatment measures to prevent loss of vision due to extensive scarring or corneal perforation (TOLAR et. al., 2006). Etiologic diagnostic and antimicrobial treatment choice are established by culture and sensitivity testing (GELATT, 2003; SLATTER, 2005; 2007; LAUS, 2009).
Gram-positive bacteria, especially Staphylococcus spp are most often identified from animals with external ocular diseases and the prevalence rates may be results of the influence of season, dog breed, geography, climate and previous treatment (PRADO et. al., 2005; 2006; LIN; PETERSEN-JONES, 2007; WANG et. al., 2008).

The purpose of this study was to determine the bacterial microorganisms and their respective susceptibility to antimicrobials in dogs' with external ocular diseases, and identify risk factors associated to external ocular diseases.

\section{Material and Methods}

Ocular specimens of 38 dogs (19 males and 19 females) with ocular disorders were collected over a 12-month period (august 2008 to july 2009) at Veterinary Teaching Hospital of North Paraná State University, Brazil. Eye compromising was confirmed by observing unilateral or 
bilateral external ocular changes as chemosis, conjunctival hyperemia, conjunctival haemorrhage, mucopurulent ocular discharge, blefarospasm, epiphora or tear deficit, photophobia, corneal edema or corneal vascularization and pigmentation. Sterile swabs were passed direct on inferior conjunctival sac of compromised eye avoinding contact with eyelashes and skin of eyelids. The swabs were transferred immediately to the laboratory and incubated in blood agar and McConkey agar at $37^{\circ} \mathrm{C}$ in an aerobic environment for 120 hours. Those without bacterial growth and exceeding 120 hours were treated as negative results.

Isolated microorganisms were identified by colony macroscopic characteristics, Gram staining, catalase test, lisostafine oxidase test and coagulase test, according to Koneman (2001). For species identification APISTAPH (bio-Merieux, Inc.), API 20 STREP (bio-Merieux, Inc.) e BACTRAY (Laborclin, ltda.) systems were used.

Antimicrobial sensitivity profile followed Bauer et al. (1966) recommendations. Colonies were tested to amikacin, amoxicillin/ clavulanic acid, ampicillin, cephalexin, ceftriaxone, ciprofloxacin, chloramphenicol, gentamicin, moxifloxacin, neomycin, norfloxacin, ofloxacin, polimyxin B, sulphonamide, tetracycline and tobramycin. Results interpretation was done according to Koneman (2001).

To obtain epidemiological information, each owner of 38 dogs with external ocular disease responded to a questionnaire prepared with different variables (season, weight, breed, gender, hair coat, feeding, presence of ectoparasites, immunization and worming scheme, street access, presence of contacting animals, neutering and spaying, allergic diseases, previous external ocular diseases, use of antibiotics, steroids, anti-inflammatory and immunosuppressive drugs, ocular cleaning and clinical recurrence). Other 120 healthy dog owners answered the same survey to compose control group. Information obtained in the study case:control (38:120) were treated statistically with chi square and odds ratio (OR) tests in a statistical software (Epi-info 6.4d) (DEAN et al., 2001). Significative differences were considered when $\mathrm{p} \leq 0,05$.

\section{Results}

Of 38 studied cases, 13 had unilateral ocular disease and 25 bilateral, resulting in 63 specimens. There was positive culture in $46(73,02 \%)$ samples with single isolated in 42 and two isolated in 4 specimens. Gram-positive bacteria were isolated in $38(76 \%)$ specimens, Gram-negative in $10(20 \%)$ and fungal yeasts in 2 (4\%) (Table 1).

The antibiotic susceptibility profile revealed $100 \%$ resistance to sulphonamide, except for Staphylococcus intermedius (S. intermedius) $(91,67 \%)$ and Staphylococcus epidermidis (S. epidermidis) (66,67\%). Susceptibility of Staphylococcus spp., Enterococcus spp., Klebsiella pneumoniae (K. pneumoniae) and Escherichia coli (E. coli) to several antibiotics are described in Table 2. Enterobacter cloacae (E. cloacae) and fungal yeasts were not tested to antibiotic susceptibility.

Four risk factors were observed in this study: clinical recurrence $(\mathrm{OR}=59,50,7,29<\mathrm{OR}<1305,07$, $\mathrm{p}=0,00000)$, previous use of topical antibiotic $(\mathrm{OR}=19,67, \quad 3,59<\mathrm{OR}<142,50, \quad \mathrm{p}=0,00003)$, previous use of topical corticosteroids (OR=19,83, $2,08<\mathrm{OR}<474,07, \mathrm{p}=0,00232)$ and ocular cleaning $(\mathrm{OR}=23,00,6,80<\mathrm{OR}<82,90, \mathrm{p}=0,00000)$. 
Table 1. Isolated microorganisms from 63 sterile swab specimens of 38 dogs attended at Veterinary Teaching Hospital of North Paraná State University, Brazil, from 08/2008 to 07/2009.

\begin{tabular}{lc}
\hline Microorganism & Number of isolations (\%) \\
\hline Gram-positive & \\
Staphylococcus aureus & $12(24)$ \\
Staphylococcus intermedius & $12(24)$ \\
Staphylococcus lentus & $4(8)$ \\
Staphylococcus epidermidis & $3(6)$ \\
Staphylococcus xylosus & $2(4)$ \\
Enterococcus faecium & $4(8)$ \\
Enterococcus faecalis & $1(2)$ \\
Subtotal & $38(76)$ \\
& \\
Gram-negative & \\
Klebsiella pneumoniae & $4(8)$ \\
Escherichia coli & $4(8)$ \\
Enterobacter cloacae & $2(4)$ \\
Subtotal & $10(20)$ \\
Fungus & \\
Yeasts & $2(4)$ \\
\hline Total & $50(100)$ \\
\hline
\end{tabular}

Source: Elaboration of the authors.

\section{Discussion}

In this study, the isolated microorganisms $(73,02 \%)$ was similar to other surveys in dogs with corneal ulcers performed in Brazil $(74,42 \%)$ by Morales et al. (2009) and in Taiwan (70,5\%) by Lin and Petersen-Jones (2007), though other surveys had a great prevalence also reported in other brazilian area (100\%) by Prado et al. (2006) and China $(93,1 \%)$ by Wang et al. (2008). In our study, samples were carried out using sterile swabs from conjunctival sac, while Lin and Petersen-Jones (2007), Wang et al. (2008) e Morales et al. (2009) used swabs directly on ulcer surface and Prado et al. (2006) used spatulas for corneal fragments collection. These different sampling methods and places associated with varied clinical lesions may have influenced results in different studies.
In dogs with external ocular diseases there is Gram-positive bacteria predominance, being Staphylococcus and Streptococcus the most commonly isolated (WHITLEY, 2000). In our study, Gram-positive bacteria represented 76\% of isolations, and Staphylococcus spp were the most frequent $(66 \%)$. Kudirkiene, Zilinskas and Siugzdaite (2006), studied dogs with external ocular diseases in Lithuania and isolated Staphylococcus spp in $58 \%$ of their samples. Different results were obtained in dogs with corneal ulcers by Prado et al. (2005; 2006) and Lin and Petersen-Jones (2007), $56,7 \%, 45,2 \%$ and $49 \%$, respectively. Morales et al. (2009) isolated Staphylococcus in $26,55 \%$ of samples from dogs with corneal ulcer previously treated with antibiotics. 


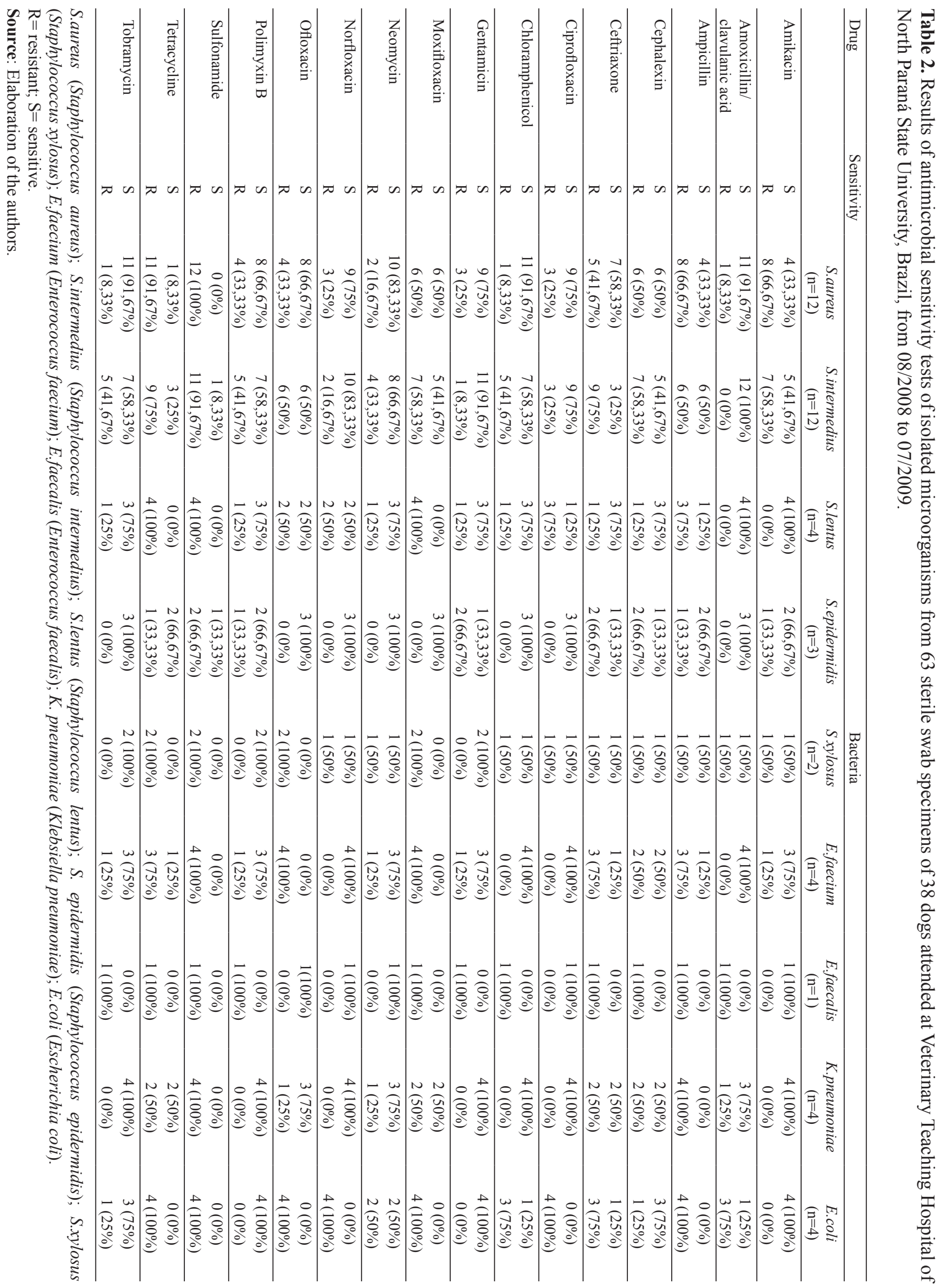


According Olliver (2003) and Laus (2009), $S$. aureus and $S$. intermedius have high pathogenic potential and represent the most important species of bacteria causing external ocular diseases. The high prevalence $(72,72 \%)$ of these two species was also isolated in Taiwan $(90,48 \%)$ by Lin and Petersen-Jones (2007) and China $(75,01 \%)$ by Wang et al. (2008). In Brazil, Prado et al. (2006) isolated $S$. aureus and $S$. intermedius in $92,92 \%$ of the specimens collected from dogs with corneal ulcer. Different prevalence of these bacteria in studies performed in Brazil and other countries probably results from factors as climate, geographic location and season.

Other Staphylococcus species as S. lentus (8\%), S. epidermidis (6\%) e $S$. xylosus (4\%) have also been reported by Andrade et al. (2002) and Wang et al. (2008) of samples of healthy dogs. These species are considered normal members of skin microbiota, are frequently isolated from cutaneous wounds and are less pathogenic than S. aureus (HIRSH; ZEE, 2003; QUINN et al., 2005).

Gram-positive and Gram-negative bacteria from intestinal environment are considered opportunist agents in several infectious processes (HIRSH; ZEE, 2003; QUINN et al., 2005). In this study, the isolation of intestinal bacteria as Enterococcus spp (10\%), K. pneumoniae (8\%), E. coli $(8 \%)$ and E. cloacae (4\%), suggest that environmental contamination and poor hygiene can contributed to the occurrence of these bacteria in ocular diseases.

The knowledge of the antimicrobials sensitivity of microorganisms isolated from the external eye diseases is critical in determining the most effective treatment and avoids the selection of antibiotic resistant bacteria.

Sulfonamide inefficiency in the treatment of external ocular diseases in this study could be confirmed by resistance detected in Gram -positive and Gram-negative bacteria isolated with exception to $S$. intermedius $(91,67 \%)$ and $S$. epidermidis $(66,67 \%)$. As the main strategy in ocular diseases is to eliminate the infection and reduce damage to the ocular surface, sulfonamides, if used, could allow the involvement of the cornea and conjunctiva of dogs surveyed.

The mean sensitivity of $S$. aureus and $S$. intermedius, most important agents causing ocular infections, to amoxicillin/clavulanic acid $(95,84 \%)$, gentamicin (83,33\%), norfloxacin $(79,17 \%)$, ciprofloxacin (75\%), chloramphenicol (75\%), neomycin $(75 \%)$ and tobramycin $(75 \%)$ indicates these antibiotics as appropriate choice of treatment before laboratory results. Similar sensitivity results with both Staphylococcus species were found to amoxicillin/clavulanic acid $(95,55 \%)$, ciprofloxacin $(89,6 \%)$ and chloramphenicol $(69,75 \%)$ by Lin and Petersen-Jones (2007). The mean resistance of $S$. aureus and $S$. intermedius to tetracycline $(83,34 \%)$, amikacin $(62,5 \%)$, ampicillin $(58,34 \%)$ and ceftriaxone $(58,34 \%)$ may be considered high, precluding the use of antimicrobials in clinical practice. Similar resistance results for Staphylococcus species were found to tetracycline (72,9\%) and ampicillin (71\%) by Lin and PetersenJones (2007).

All Enterococcus bacteria isolated were sensitive to norfloxacin and ciprofloxacin and resistant to moxifloxacin. Lin and Petersen-Jones (2007) and Massa et al. (1999) described the isolation of this bacteria in dogs with external eye diseases, but did not evaluate the antimicrobial sensitivity. In dogs with skin wounds, peritonitis or endocarditis by Enterococcus, the choice antibiotics are vancomicyn and penicillin, not tested in the present study. Sulfonamides are not efficient because this agent has high acquired and natural resistance to this antibiotic (GREENE, 1990; PAPICH, 2008).

The specimens of $K$. pneumoniae and E. coli showed sensitivity to gentamicin, polimycin and amikacin and the same percentage of ampicillin resistance. Lin and Petersen-Jones (2007) had $67 \%$ of $E$. coli isolated from corneal ulcers in dogs showing sensitivity to amikacin and $86 \%$ resistant to 
ampicillin and tetracycline. There are deficiencies in antimicrobial sensitivity studies of Gram-negative bacteria isolated from external eye diseases in dogs.

Fungal diseases on the ocular surface are rare but may be caused by Candida and Aspergillus (SAMUELSON; ANDRESEN; GWIN, 1984; MASSA et al., 1999). The predisposing factors for ocular fungal infection are inappropriate use of antibiotics, corticosteroids or immunosuppressive drugs for a prolonged periods, as well as the presence of mycotic blepharitis concomitant with bulbar lesions, which may predispose to yeast infections like Mallassezia sp (KONEMAN, 2001; SLATTER, 2005; LAUS, 2009). The presence of yeasts in two dogs of this study may be due to improper use of ocular drugs previously by the owners.

The previous use of eye drops with antibiotics and steroids, administered as inadequate frequency or period, are associated with external eye diseases and can cause clinical recurrence, with selection and multiplication of eye microbiota, slow healing corneal epithelium, suppression of inflammatory mechanisms and enhancement of corneal ulceration (OLLIVIER, 2003; PRADO et al., 2006; TOLAR et al., 2006; LAUS, 2009; MORALES et al., 2009).

In the studied population, the cleaning eye was considered a risk factor and should be done judiciously. Despite the sterile eye solutions are indicated for the removal of ocular discharge, foreign bodies and irritating material on the ocular surface, when stored inappropriately can promote bacterial growth in solution with subsequent recontamination of the cornea and conjunctiva (SLATTER, 2005; LAUS, 2009).

\section{Conclusions}

Bacterial culture confirmed Gram-positive bacteria, specifically $S$. aureus and $S$. intermedius, as the most prevalent in external ocular diseases. Sensitivity tests indicated high resistance to sulfonamide excluding this substance to treat ocular infections. The most indicated antibiotics to treat external ocular diseases caused by $S$. aureus and $S$. intermedius are gentamicin, ciprofloxacin, chloramphenicol, neomycin and tobramycin. Risk factors for external ocular disorders were presence of clinical recurrence, previous use of antibiotic or corticoids eyedrops and cleaning eyes. Microbiological and antibiogram tests are essential for the adequate treatment and cure of the external ocular diseases.

\section{Acknowledgements}

The authors would like to thank the Fundação Araucária and Secretaria da Ciência, Tecnologia e Ensino Superior do Estado do Paraná for providing resources and support to research.

This article was approved by the Ethics and Animal Experimentation Committee of the Londrina State University and registered under number 69/08.

\section{References}

ANDRADE, A. L.; STRINGHINI, G.; BONELLO, F. L.; MARINHO, M.; PERRI, S. H. V. Microbiota conjuntival de cães sadios da cidade de Araçatuba (SP). Arquivo Brasileiro de Oftalmologia, v. 65, p. 323-326, 2002.

ARMSTRONG, R. A. The microbiology of the eye. Ophthalmic Physiological Optics, v. 20, n. 6, p. 429-441, 2000.

BAUER, A. W.; KIRBY, W. M. M.; SHERRIS, J. C.; TURCK, M. Antibiotic susceptibility testing by a standardized single disk method. American Journal of Clinical Pathology, Philadelphia, v. 45, n. 4, p. 493-496, 1966.

DEAN, A. G.; DEAN, J. A.; COULOMBIER, D.; BURTON, A. H.; BRENDEL, K. A.; SMITH, D. C. Epi Info version 6.04d: a word processing, database and statistic program for public health on microcomputer. Atlanta: Centers of Disease Control and Prevention, 2001.

GREENE, C. E. Infectious diseases of the dog and the cat. 2. ed. Philadelphia: W. B. Saunders, 1990.

HIRSH, D. C.; ZEE, Y. C. Microbiologia veterinária. 2. ed. Rio de Janeiro: Guanabara Koogan, 2003. 
KONEMAN, W. K. Diagnóstico microbiológico. 5. ed. Rio de Janeiro: Medsi, 2001.

KUDIRKIENE, E.; ZILINSKAS, H.; SIUGZDAITE, J. Microbial flora of the dog eyes. Veterinarija Ir Zootechnika, v. 34, n. 56, p. 18-21, 2006.

LAUS, J. L. Oftalmologia clínica e cirúrgica em cães e gatos. São Paulo: Roca, 2009.

LIN, C. T.; PETERSEN-JONES, S. M. Antibiotic susceptibility of bacterial isolates from corneal ulcers of dogs in Taiwan. Journal of Small Animal Practice, v. 48, n. 5, p. 271-274, 2007.

MASSA, K. L.; MURPHY, C. J.; HARTMANN, F. A.; MILLER, P. E.; KORSOWER, C. S.; YOUNG, K. M. Usefulness of aerobic microbial culture and cytologic evaluation of corneal specimens in the diagnosis of infectious ulcerative keratitis in animals. Journal of the American Veterinary Medical Association, v. 215, n. 11, p. 1671-1674, 1999.

MORALES, A.; VALINHOS, M. A. R.; SALVADEGO, M.; LEVY, C. E. Microbiological and clinical aspects of corneal ulcers in dogs. In: WORLD SMALL ANIMAL VETERINARY CONGRESS - WSAVA/ FECAVA/ CSAVA. 34., 2009, São Paulo. Anais... São Paulo: [s.n], 2009. p. 195-197.

OLLIVIER, F. J. Bacterial corneal diseases in dogs and cats. Clinical Techniques in Small Animal Practice, v. 18, n. 3, p. 193-198, 2003.

PAPICH, M. G. Bacterial resistance and its management in the $21^{\text {th }}$ century. In: PROCEEDINGS OF THE WORLD SMALL ANIMAL VETERINARY ASSOCIATION WSAVA. 32., 2008, Sidney, 2008. Anais... Sidney: [s.n.], 2008. Available at: <http://www.ivis.org/proceedings/ Wsava/2007/pdf/62_20070402142232_abs.pdf > Accessed at: 15 jun. 2010.
PRADO, M. R.; BRITO, E. H. S.; GIRÃO, M. D.; SIDRIM, J. J. C.; ROCHA, M. F. G. Identification and antimicrobial susceptibility of bacterial isolated from corneal ulcers of dogs. Arquivo Brasileiro de Medicina Veterinária e Zootecnia, v. 58, n. 6, p. 33-37, 2006.

PRADO, M. R.; ROCHA, M. F. G.; BRITO, E. H. S.; GIRÃO, M. D.; MONTEIRO, A. J.; TEIXEIRA, M. F. S.; SIDRIM, J. J. C. Survey of bacterial microorganisms in the conjunctival sac of clinically normal dogs and dogs with ulcerative keratitis in Fortaleza, Ceará, Brazil. Veterinary Ophthalmology, v. 8, n. 1, p. 33-37, 2005.

QUINN, P. J. Microbiologia veterinária e doenças infecciosas. Porto Alegre: Artmed, 2005.

SAMUELSON, D. A.; ANDRESEN, T. L.; GWIN, R. M. Conjunctival fungal flora in horses, cattle, dogs, and cats. Journal of the American Veterinary Medical Association, v. 184 , n. 10 , p. $1240-1242,1984$.

SLATTER, D. Fundamentos de oftalmologia veterinária. 3. ed. São Paulo: Roca, 2005.

. Manual de cirurgia de pequenos animais. 3. ed. Barueri : Manole, 2007. 2v.

TOLAR, E. L.; HENDRIX; D. V. H.; ROHRBACH, B. W.; PLUMMER, C. E.; BROOKS, D. E.; GELATT, K. N. Evaluation of clinical characteristics and bacterial isolates in dog with bacterial keratitis: 97 cases (19932003). Journal of the American Veterinary Medical Association, v. 228, n. 1, p. 80-85, 2006.

WANG, L.; PAN, Q.; ZHANG, L.; XUE, Q.; CUI, J.; QI, C. Investigation of bacterial microorganisms in the conjunctival sac of clinically normal dogs and dogs with ulcerative keratitis in Beijing, China. Veterinary Ophthalmology, v. 11, n. 3, p. 145-149, 2008.

WHITLEY, R. D. Canine and feline primary bacterial infection. Veterinary Clinics of North America, v. 30, $\mathrm{n}$. 5, p. 1151-1167, 2000. 